\title{
CHRISTIANITY FOR ALL. A FEW WORDS ON QUIDAM BY C. NORWID ${ }^{1}$
}

Most Distinguished Ladies and Gentlemen, Dear Friends,

I would like to express my most sincere gratitude to the Norwid Foundation for this honourable distinction. I would like to thank dear Mirosława HanusiewiczLavallee for her touching laudation and all the colleagues, Norwid Studies experts gathered here today, for their long-standing support.

Thank you very much for the opportunity to say a few words about my interpretation of the poem Quidam, based on my book Zaproszenie do Quidama. ${ }^{2}$ The book is not entirely a novelty, but it is also not entirely conventional.

I will start with a few statements about Norwid's treatment of time and the synthetic character of many of the moments presented in Quidam. Norwid regarded Christ's appearance on earth as the starting point of a silent, slowly progressing revolution which binds a long prehistory in the form of Greek culture and Judaism, the difficult topicality of the multicultural Roman civilisation of the time of Emperor Hadrian, and an extensive prospect of the future reaching (though not only) to the $19^{\text {th }}$ century. Specifically, in the poem this is subtle, slow revolution is presented through the overwhelming effect of mirrors within the mirror. Rome is reflected in itself in all phases of its history, but also in new Romes, such as St. Petersburg, London and Paris. A similar phenomenon can be observed in the case of each of the main protagonists in the poem. I will give here just one example: the Greek philosopher, Artemidorus, reflects - in a highly discreet and allusive

${ }^{1}$ A slightly edited version of the speech delivered by the laureate of the "Medal for the Dissemination of Knowledge about Cyprian Norwid" at the Catholic University of Lublin on 16 October 2017.

${ }^{2}$ R. Fieguth, Zaproszenie do “Quidama." Portret poematu C. Norwida, Kraków 2014. 
manner - many characters of different times, including Plato and Seneca, but also, almost explicitly, any trendy philosopher active in the $19^{\text {th }}$ century in France - and, I think, also Zygmunt Krasiński, and probably, at least slightly, August Cieszkowski. Similar effects are allusively present in all other main and many side characters of Quidam.

There are also whole episodes which trigger the mirror in a mirror effect. The most important of these is the Jewish uprising which reflects all previous antique, non-Jewish and Jewish uprisings, but also modern European uprisings, especially the Polish ones. This effect is connected with the special treatment of time in Quidam. The traditional concept of the chronological passing of time is competing here with the principle of eternity, i.e. the timeless simultaneity of what we call the past, present and future. The result of the coexistence of these two concepts is that many moments presented in the poem are synthetic, even within the limits of the adopted time frame. The action of the poem develops in two seemingly uninterrupted sequences of several days, maybe three or four days, separated by an indefinite longer period from Barchob's departure to Palestine until a messenger of the Jewish uprising appears in front of Jason. But an element of the longer duration is also included in each of the two time sequences, and it is "left unsaid" in them. An example of that is the scene of a philosophical séance in Artemidorus's house which is both a "one-time" event and a synthesis of many similar silent séances where Aleksander's Son was or would be present. Similarly, the three explicit encounters between Alexander's Son and Sophie are a synthesis of a much longer and more frequent contact, which is not entirely left unsaid, as the diary of the poem's protagonist informs us about it. A synthesis of frequent meetings between Emperor Hadrian and the philosopher Artemidorus is also a description of one of them in Book XIX - the same applies to many other episodes in Quidam. I will stress that similar time syntheses are primarily grounded in the narrative time during the actual Emperor Hadrian's reign; another thing is that some of the presented moments may additionally participate in wider temporal effects of mirrors in a mirror, covering both pre-Hadrian and much later periods. With all this in mind, the work resembles a condensed rhymed novel sometimes close to a drama about the fate of a group of protagonists at some point in time during Hadrian's reign in Rome - and at the same time, it continues to grow into a Roman "parable" i.e. an alternative novel, and further into a miniature Christian human epic with great historical scope and with sophisticated allusions to the situation of $19^{\text {th }}$ century Europe and Poland.

In Norwid's vision of the process triggered by Christ's Revolution as well as in Quidam's narrative, two aspects coexist: the aspect of "gentle law" and that of drastic events. Encouraged by Christian Zehnder, I borrowed the term "gentle 
law" (das sanfte Gesetz) from Adalbert Stifter. ${ }^{3}$ According to the "gentle law" principle, this process operates discreetly, most often on the far periphery of collective and individual consciousness beyond the clear knowledge of people and humanity, but it is as unstoppable as the increase in the level of the groundwater. On the other hand, the same process sometimes manifests itself through very drastic and brutal events, which in Quidam range from the three murders of the poem's protagonists to the Jewish insurrectionary war in Palestine - however, all these events are linked to Christ's trial in many different ways. The conflict between these two aspects in Quidam is most pronounced in the competition between the effects of the "gentle law" on the reactions and the conscience of the individual heroes of the poem and the theme of the "messianic" Jewish uprising and the reaction of Hadrian's regime.

The silent Christian Revolution affects the private reactions and fates of each main protagonist of the poem without them being aware of it, but in a very differentiated way. All or almost all people described in Quidam are to some extent witnesses or even priests of this revolution mostly "unaware and unformed" (see Poem XV from Vade-mecum - Sfinks [Sphinx]). Not knowing this or even denying it, they carry - to a varying extent - with, on or within themselves the traces of this silent revolution.

The symptoms of the new era of Christ in private life can be seen in the poem's love story, which, according to me, so far has not sparked any considerable interest in the research on the poem. Men and women in the poem are at the very beginning of becoming individuals and loving in the "present" sense, i.e. recognising in the person they love another Self, another individual. The couple Lucius Pomponius and Electra-Diva is still mostly stuck in this pagan, bare eroticism. But even the Roman dandy Lucius has an almost grotesque remorse as a result of his love for the Greek hetaira and poetess Sophie. By contrast, Electra, a young circus dancer, is at one point drawn to Jason, in almost a comical way, not realising that he is a priest of God of both Abraham and Paul of Tarsus, and that his name is the Hellenised form of the name Joshua or Jesus.

The beautiful Sophie is also strangely attracted to the same Jason whom she expects to cure her from the disease of love. She is kept as a mistress, in an older antique spirit, by the Greek philosopher Artemidorus. On the other hand, the young Alexander of Epirus, a seeker of wisdom and truth, or a poet, loves her in an already quite Christian spirit, not completely without reciprocity, and yet

3 Adalbert Stifter, an outstanding Austrian writer (1805-1868). The concept of the "gentle law" governing the world independently of human initiatives was laid out in the foreword to a two-volume collection of prose sketches, entitled Bunte Steine. Ein Festgeschenk [Colourful Stones], Pest 1853. 
unhappily because without the achieving unity of conscience and souls. But some Christian elements have accompanied Sophie since the beginning of the poem, for example, due to the rich Greek, Jewish and Christian allusions contained in her name, but also in the form of her Egyptian maid, a patient and cheerful Christian woman, most likely conceived by Norwid as a secret Christian. A Christian accent can also be found in the scene of the last meeting of the degraded "pilgrim" Artemidorus with the dying Sophie because at this point they both dropped their previous egoisms. The former imperial philosopher, and now an outlaw, no longer cares about his own skin, but participates in Sophie's funeral despite the ban on staying in Rome; in Norwid's view this is already a Christian act.

Let me reiterate, at the end of this short lecture I do not want to diminish the role of Alexander's Son - he is the most prominent example of the Christian influence in the poem. However, my thesis is that it is not only him, but also all the other protagonists of the work that are in one way or another connected with this Christian sphere - including both Artemidorus and Sophie, and especially Rabbi Jason and Barchob. And one more thing: the Christian sphere also includes certain parts of the Roman people, quite richly characterised in the poem. The first quidam emerges from the people, a gardener who, with his companions, stands before the Roman public court, and the second, quidam, who preaches over the corpse of Alexander's Son. All in all, it can be stated that in Quidam - with the exception of Roman religious practices - every other culture, philosophy and religion present in Emperor Hadrian's capital is treated with great respect, but with a very discreetly outlined perspective of their future conflation in Christianity in its broadest sense. 